\title{
HepK, a protein-histidine kinase from the cyanobacterium Anabaena sp. strain PCC 7120, binds sequence-specifically to DNA
}

Ruanbao Zhou ${ }^{1,2^{*}}$ and Olga A. Koksharova ${ }^{2,3}$

*Correspondence: Ruanbao.zhou@sdstate.edu

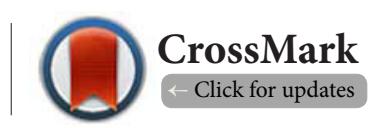

'Department of Biology and Microbiology, South Dakota State University, Brookings, SD 57007, USA.

${ }^{2}$ MSU-DOE Plant Research Laboratory, Michigan State University, East Lansing, MI 48824, USA.

${ }^{3}$ M.V. Lomonosov Moscow State University, A.N. Belozersky Institute of Physico-Chemical Biology, Leninskie Gory, 1, str. 40,

Moscow 119992, Russia.

\begin{abstract}
Two-component phosphorelay systems are minimally consisted of a sensory protein-histidine kinase (HK) and a response regulator (RR). HK autophosphorylates its conserved histidine residue in response to stimulus from an environment, this phosphate group then is transferred to a conserved aspartic acid residue of an RR, which is generally a transcription factor. HepK is a member of the family of sensory protein-histidine kinases in two-component phosphorelay systems (TCPS). We previously showed that HepK is an autokinase, and that DevR is its cognate RR, together comprising a mini two-component phosphorelay system that mediates developmental regulation of biosynthesis of a heterocyst envelope polysaccharide in the cyanobacterium Anabaena sp. PCC 7120. Unlike a typical TCPS, both HepK and DevR lack known DNA-binding domains. However, mutations in $h e p K, h e p C$ and $h e p A$ all block the synthesis of heterocyst envelope polysaccharide. A hepK mutation of Anabaena blocks the induction of hepA expression. We hypothesized that HepK may regulate transcription of hepA or hepC by binding to DNA. To test this hypothesis we have performed a gel-shift analysis and have shown that although lacking a known DNA-binding motif, a truncated, soluble version of HepK binds sequence-specifically to a fragment of DNA found upstream from $h e p C$, a gene that is located immediately upstream from $h e p A$ and also required for the synthesis of heterocyst envelope polysaccharide. The conserved phosphorylation histidine residue of HepK kinase is not required for this DNA-binding activity. Therefore, regulation of the synthesis of heterocyst envelope polysaccharide by HepK may be, at least in part, independent of two-component phosphorylation. The membrane-anchored HepK kinase with specific DNA-binding activity may serve as a membrane-tethered transcription factor, which may require an activation of regulated intramembrane proteolysis. We have found no other example of a protein histidine kinase without a known DNA binding motif that binds DNA sequence-specifically. Our finding may enable development of small DNA molecule as highly specific anti-microbial drugs because protein histidine kinases are broadly conserved in microbial pathogens but absent in humans.
\end{abstract}

Keywords: Cyanobacterium, heterocyst, hepA, hepC, histidine kinase binds DNA, DNA drug

\section{Introduction}

Two-component phosphorelay regulatory systems are widespread in prokaryotes, and are found also in fungi, amoebae and plants $[1,2]$. Typically, a sensory protein-histidine kinase phosphorylates its own conserved histidine residue in response to an environmental stimulus. Histidine kinases are not commonly known to function by binding to DNA, although they have been shown to regulate the transcription of target genes indirectly by activation of a specific response regulator. Response regulators generally contain an $\mathrm{N}$-terminal regulatory domain with a conserved aspartate residue, to which the phosphoryl group of the kinase is transferred, and a variable C-terminal effector domain [3]. The response-regulator protein usually regulates the expression of certain genes to effect an adaptive response [4]. Most known 
Zhou et al. Trends in Bacteriology 2014,

http://www.hoajonline.com/journals/pdf/2057-4711-1-3.pdf

doi: 10.7243/2057-4711-1-3

response regulators are transcription factors whose effector domains bind DNA. However, some response regulators have no known effector domain [1] and the effector domain of some others are enzymatically active $[5,6]$.

Three proteins with similarity to members of two-component regulatory systems are known to influence heterocyst development in filamentous cyanobacteria. HepK was identified as a sensory protein-histidine kinase [7] and DevR and PatA resemble response regulators. All three lack known DNA-binding domains $[7,9,10]$. Mutations in hepK, hepC and hepA all block the synthesis of heterocyst envelope polysaccharide, rendering the heterocysts incapable of $\mathrm{N}_{2}$ fixation under aerobic conditions $[10,11]$. A hepK mutation of Anabaena sp. strain PCC 7120 blocks the induction of hepA, whereas inactivation of hepC, located directly upstream from hepA, leads to constitutive expression of hepA [10].

The catalytic core of histidine kinases, including of HepK, contain highly conserved regions (the $\mathrm{H}, \mathrm{N}, \mathrm{D} / \mathrm{F}, \mathrm{G} 1$ and $\mathrm{G} 2$ boxes) that are distinct from the previously characterized Ser/Thr/Tyr kinase domain [12]. That catalytic core does not appear to be obligatorily dependent upon catalytic phosphorylation of a His rather than a Ser, Thr, or Tyr, because histidine kinase homologs are known in which the phosphorylated His is substituted by Tyr [13] or Ser [14]. Unanticipated similarities of the catalytic core to DNA gyrase B and to DNA-mismatch-repair enzyme MutL $[12,15,16]$ provide hints that a histidine kinase might be able to interact directly with DNA. We previously demonstrated that HepK is a sensory protein-histidine kinase in HepK-DevR two-component regulatory system [7]. Because HepK may regulate the transcription of hepA or hepC, we tested whether HepK can bind DNA upstream from these genes. We report here that a water-soluble version of HepK that lacks the two putative transmembrane regions of that protein is a histidine kinase that binds sequence-specifically to DNA upstream from hepC. Therefore, the regulation of the synthesis of heterocyst envelope polysaccharide by HepK may be, at least in part, independent of two-component phosphorylation. Except for a kinase that bears a presumptive response regulator with a DNA-binding motif [17], we have found no other known example of a histidine kinase that binds DNA sequence-specifically.

\section{Materials and methods}

\section{Production and purification of truncated HepK}

Unable to produce catalytically active, intact HepK (GenBank accession no. U68034) by expression in Escherichia coli, we produced a truncated, water-soluble version of HepK that lacks two presumptive transmembrane regions, as follows. A 3'-terminal portion of hepK encoding residues 267-575 of HepK was amplified by PCR with primers 5'-GGAATTCCATATGCGGACTAGTCGAGCGATCGCT-3' and 5'-CGGGATCCTAACTTTGCTCCTGAAGTG-3' (introduced Ndel and BamHI sites are underlined). The PCR product was cloned between the Ndel and BamHI sites of plasmid pET-14b (Novagen, Inc., Madison, WI), which provided an $\mathrm{N}$-terminal hexa-histidine tag. The resulting plasmid was de- noted $\mathrm{pRL} 2406$, and the tagged, truncated product was denoted $\mathrm{H}_{6}{ }^{-}{ }^{-} \mathrm{HepK}$. DNA sequencing confirmed that the PCR product was error-free. To overproduce $\mathrm{H}_{6}{ }^{-}{ }^{\prime} \mathrm{HepK}$, Escherichia coli strain BL21 (DE3) transformed with pRL2406 was grown in $500 \mathrm{ml} \mathrm{LB}$ medium supplemented with $100 \mathrm{~g} \mathrm{ml}^{-1}$ ampicillin at $37^{\circ} \mathrm{C}$ to an $\mathrm{OD}_{600}$ of $0.5-0.6,0.5 \mathrm{mM}$ isopropyl- $\beta$-D-thiogalactopyranoside was added, and incubation was continued for $5 \mathrm{~h}$. $\mathrm{H}_{6}-{ }^{-} \mathrm{HepK}$ was purified to homogeneity as follows: E. coli suspended in $50 \mathrm{mM}$ Na phosphate, $100 \mathrm{mM} \mathrm{NaCl}$, pH 7.0, was broken with a French press (American Instrument Co. Div. Travenol Laboratories, Inc., Silver Spring, MD). The supernatant solution from centrifugation for $20 \mathrm{~min}$ at $20,000 \times \mathrm{g}$ at $4^{\circ} \mathrm{C}$ was applied to a cobalt-based resin column (Clontech Laboratories, Inc., Palo Alto, CA), which was then washed thrice with $50 \mathrm{mM}$ Na phosphate, $300 \mathrm{mM}$ $\mathrm{NaCl}, 5 \mathrm{mM}$ imidazole, pH 7.0. $\mathrm{H}_{6}{ }^{-}{ }^{-} \mathrm{HepK}$ eluted with $50 \mathrm{mM}$ Na phosphate, 300 mM imidazole, pH 5.5, was loaded onto a Sephadex G-100 gel-filtration column (Amersham Pharmacia Biotech Inc., Piscataway, $\mathrm{NJ}$ ) from which it was eluted at $4^{\circ} \mathrm{C}$ with $50 \mathrm{mM}$ Na phosphate, $100 \mathrm{mM} \mathrm{NaCl}, \mathrm{pH}$ 7.0, at $20 \mathrm{ml} \mathrm{h}^{-1}$. Hexahistidine-tagged DevR ( $\mathrm{H}_{6}$-DevR) and hexa-histidine-tagged mutant 'HepK ( $\left.\mathrm{H}_{6}-{ }^{\prime} \mathrm{HepK}-\mathrm{H} 348 \mathrm{~A}\right)$ were prepared as described previously [7].

Gel mobility shift assay in vitro for DNA-protein complexes Mobility shift assays [19] were performed with a "DIG Gel Shift Kit" (Roche Molecular Biochemicals, Indianapolis, IN) according to [20]. The DNA probes used in these experiments are shown in Figure 1. The DNA probes were prepared by $P C R$ with the following primers: A1, 5'-GCTCTAGAATTAGGTTTATCC-3' and 5'-GAAATGGATTGAATACAATCCTC-3'; B2, 5'-CCGAATTCTACAGAGCTTTGTTTCTCAG-3' and 5'-GATATGAATTCGACAACCTAATTTTTAAC-3'; X1, 5'-ATCGATTTTTTAACATAAATTGCC-3' and 5'-TACTTGTTTACTTGCACAATAATTTTC-3'; X12, 5'-CTATGACTATTTAAAGAG-3' and 5'-TACTTGTTTACTTGCACAATAATTTTC-3'; X2, 5'-CAAAGGTTAGGTTAATTGCC-3' and 5'-CGATTTTTAAAATCAGTATCC-3', and X13, 5'-TCCACAATATTTAAGTATTTTAT-3' and 5'-GGATATAAGACTCTGTAGAAATG-3'. The DNA fragments were 3'-end-labeled by using DIG-11-ddUTP and terminal transferase. Labeled DNA probes $(0.4-0.8 \mathrm{ng})$ were incubated with $0.3 \mu \mathrm{g}$ of purified $\mathrm{H}_{6}-{ }^{-} \mathrm{HepK}$ or $\mathrm{H}_{6}{ }^{-}{ }^{\prime} \mathrm{HepK}-\mathrm{H} 348 \mathrm{~A}$ (protein) in binding buffer (25 mM HEPES, pH 7.9, $5 \mathrm{mM} \mathrm{MgCl}, 25 \mathrm{mM} \mathrm{NaCl}, 0.5 \mathrm{mM}$ DTT, $5 \%$ glycerol, $5 \mu \mathrm{g} \mathrm{BSA})$ containing $0.5 \mu \mathrm{g}$ of poly-(dl-dC/dl-dC) in a final volume of $20 \mu \mathrm{l}$. For gel shift competition, $\mathrm{H}_{6}{ }_{-}{ }^{-} \mathrm{HepK}$ or $\mathrm{H}_{6}{ }_{6}{ }^{-} \mathrm{HepK}-\mathrm{H} 348 \mathrm{~A}$ was bound with at least 75-fold excess (75to 270 -fold molar ratios based on the molecular weight of the competitor DNAs) of unlabeled competitor DNA for $15 \mathrm{~min}$ at room temperature before addition of the probe. Incubation with the probe lasted for $20 \mathrm{~min}$. The mixture was then loaded on an $8 \%$ polyacrylamide gel (30:1 acrylamide-bisacrylamide) in Tris-glycine buffer (50 mM Tris, $380 \mathrm{mM}$ glycine, 2 mM EDTA, $\mathrm{pH} 8.5$ [19]) that had been pre-run for $1 \mathrm{~h}$ at $4^{\circ} \mathrm{C}$ and $140 \mathrm{~V}$. Electrophoresis was performed at $4^{\circ} \mathrm{C}$ in a Tris-glycine buffer, for 2 to $2.5 \mathrm{~h}$ at a constant voltage of $140 \mathrm{~V}$ (ca. $30 \mathrm{~mA}$ ). The gel was then electroblotted onto a Hybond-N+ Nylon membrane 
Zhou et al. Trends in Bacteriology 2014,

http://www.hoajonline.com/journals/pdf/2057-4711-1-3.pdf

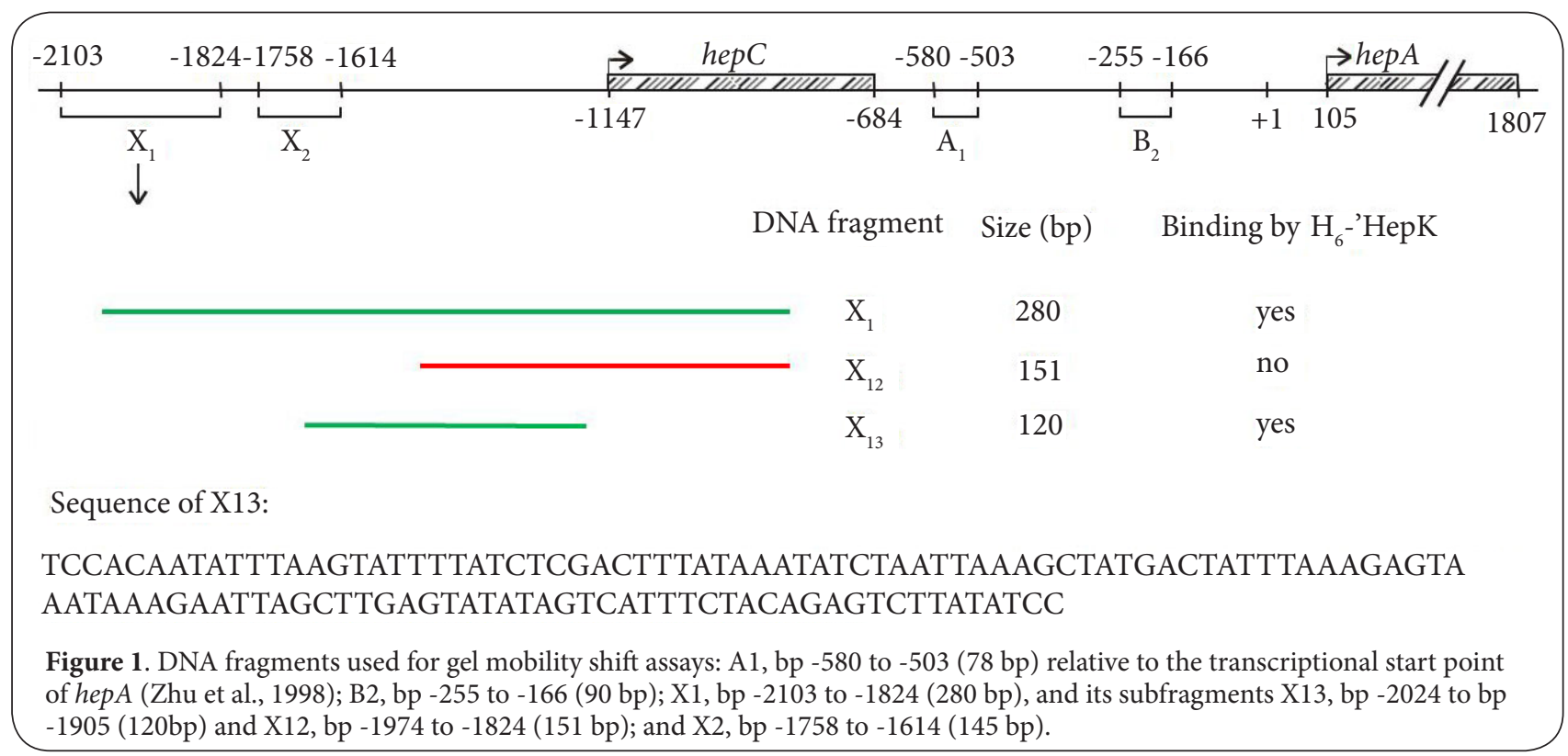

(Amersham Pharmacia) at $200 \mathrm{~mA}$ in the same Tris-glycine buffer at $4^{\circ} \mathrm{C}$ for $1 \mathrm{~h}$, the membrane baked at $80^{\circ} \mathrm{C}$ for $2 \mathrm{~h}$, and chemiluminescence detected according to the manufacturer's instructions.

\section{Results}

Recombinant $\mathrm{H}_{6}{ }_{6}{ }^{-} \mathrm{HepK}$, overexpressed in E. coli and purified to homogeneity (Figure 2A, lane 3 ), binds fragment $X 1$ (Figure 3A, lane 2), and also X13 (Figure 3B, lane 2), a subfragment of $X 1$ (Figure 1), but not fragments X2, B2, A1 and $X 12$ (Figure 3A, lanes 3-10 and Figure 1). Competition experiments with unlabeled $\mathrm{A} 1$ showed that a 75 -fold excess of A1 (by mass; 270 -fold molar excess) does not significantly affect the formation of a complex between $\mathrm{X} 1$ and $\mathrm{H}_{6}-{ }^{\prime} \mathrm{HepK}$ (Figure 3C, lanes 3 and 5), whereas a 75-fold excess of $\mathrm{X} 1$ reduces complex-formation by approximately $90 \%$ (Figure $3 \mathrm{C}$, lanes 4 and 3). Phosphorylation of $\mathrm{H}_{6}{ }^{-}{ }^{\prime} \mathrm{HepK}$ is labile to acid and stable to alkali, supporting the idea that its site of autophosphorylation is a histidine residue $[7,22]$; the $\mathrm{H} 348 \mathrm{~A}$ substitution abolishes autophosphorylation [7]; and (unphosphorylated) $\mathrm{H}_{6}{ }^{-}$'HepK-H348A binds X1 specifically (Figure 4, lane 2). Competition experiments with unlabeled $A 1$ (Figure 4, lane 4) and unlabeled X1 (Figure 4, lane 3) showed similar results to that of wild-type $\mathrm{H}_{6}-{ }_{-}$'HepK (Figure $3 \mathrm{C}$, lanes 5 and 4). These results provide additional information that the specific binding does not require phosphorylation. The control experiment, the purified $\mathrm{H}_{6}-$ DevR protein (Figure 2B, lane 3) produced no mobility shift of $\mathrm{X} 1$ (Figure $3 \mathrm{C}$, lane 2), showing that the site-specific binding by $\mathrm{H}_{6}-{ }^{\prime} \mathrm{HepK}$ is not due to the hexa-histidine tag.

\section{Discussion}

Several bacterial proteins with high homology to histidine

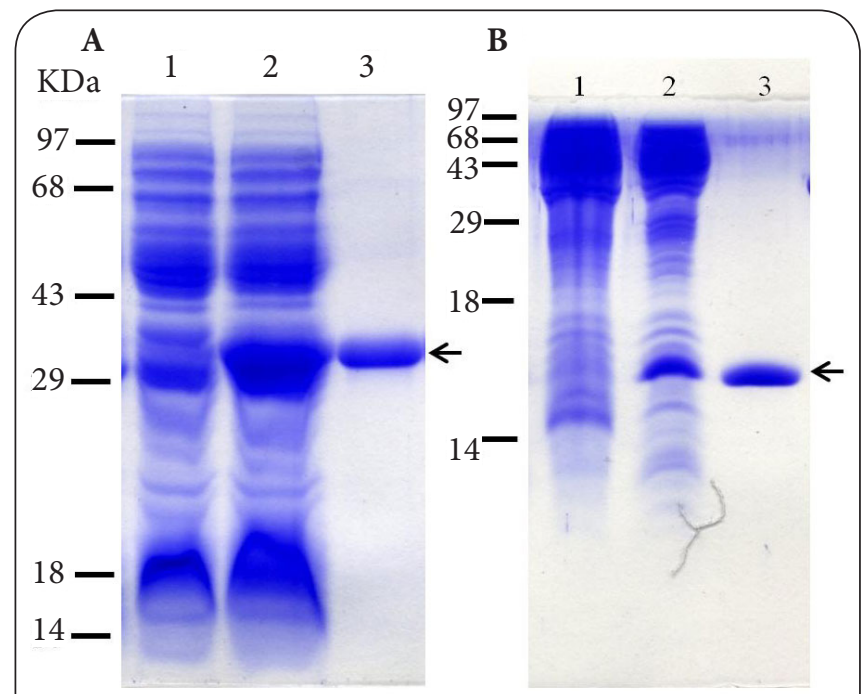

Figure 2. SDS-PAGE analysis of recombinant $\mathrm{H}_{6}{ }^{-}{ }^{\prime} \mathrm{HepK}$ (A) and $\mathrm{H}_{6}-\operatorname{DevR}(\mathbf{B})$.

A: $\mathrm{kDa}$, protein standards (molecular masses in $\mathrm{kDa}$ ) shown to the left of lane 1. Lane 1, total extracts of E. coli BL21 (DE3) bearing pET-14b. Lane 2, total cell extracts of E. coli BL21 (DE3) bearing pRL2406 induced with IPTG. Lane 3, $\mathrm{H}_{6}{ }^{-}{ }^{-} \mathrm{HepK}$ $(\sim 20 \mu \mathrm{g}$ in $10 \mu \mathrm{l})$ purified by a cobalt-based affinity column followed by Sephadex G-100 chromatography.

B: Lane 1, total extracts of E. coli BL21 (DE3) bearing pET14b. Lane 2: total cell extracts of E. coli BL21 (DE3) bearing pRL2461 (Zhou \& Wolk, 2003) induced with IPTG. Lane 3, $\mathrm{H}_{6}$-DevR $(\sim 10 \mu \mathrm{g}$ in $10 \mu \mathrm{l})$ purified by a cobalt-based affinity column followed by Sephadex G-100 chromatography. The $12 \%$ polyacrylamide gel (A) and the $15 \%$ polyacrylamide gel (B) were stained with Coomassie brilliant blue R-250.

kinases are apparently not kinases [1]. For example, Azotobacter vinelandii NifL contains five conserved blocks characteristic 

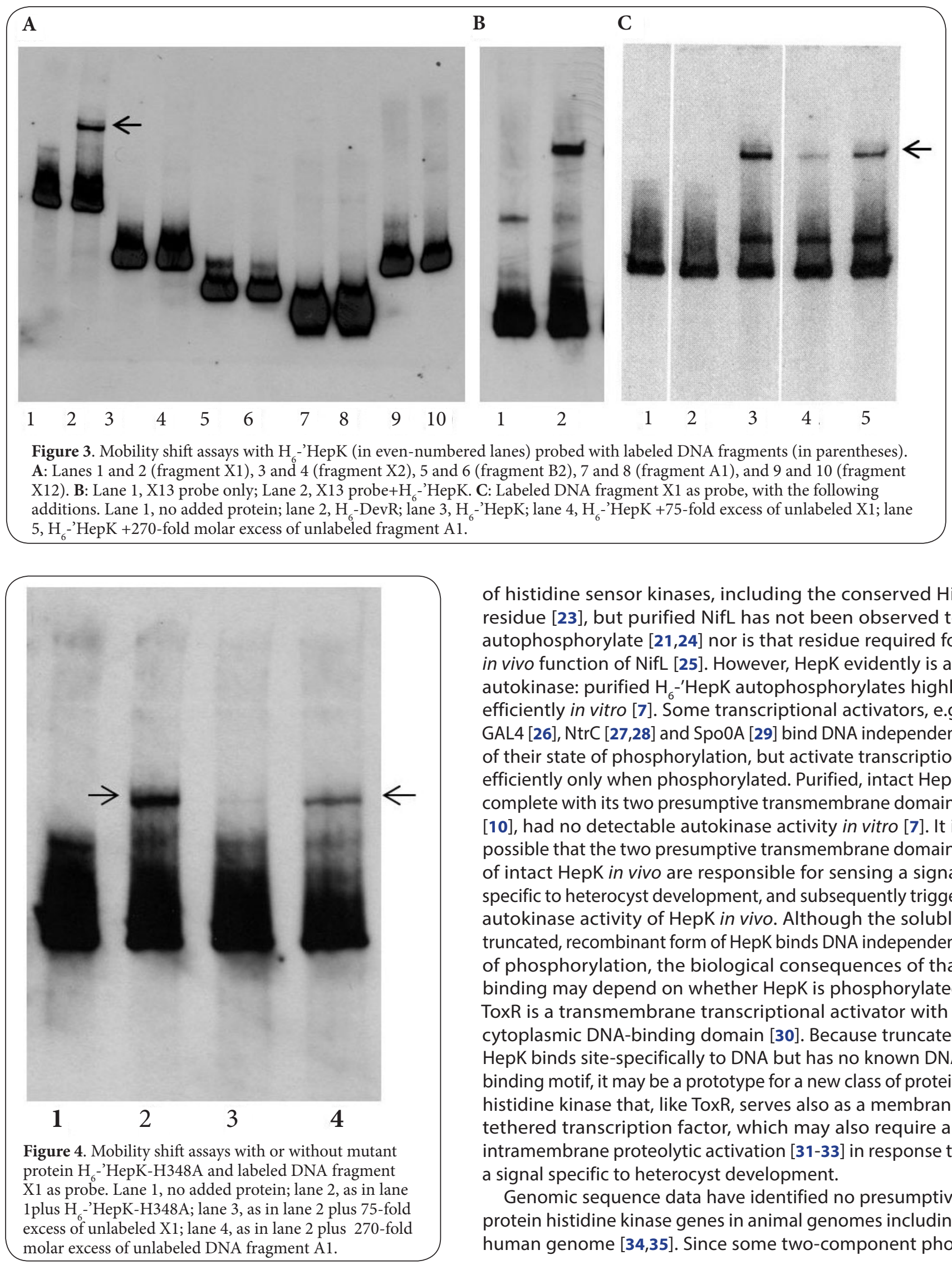

of histidine sensor kinases, including the conserved $\mathrm{His}$ residue [23], but purified NifL has not been observed to autophosphorylate $[\mathbf{2 1 , 2 4 ]}$ nor is that residue required for in vivo function of NifL [25]. However, HepK evidently is an autokinase: purified $\mathrm{H}_{6}{ }^{-}$'HepK autophosphorylates highly efficiently in vitro [7]. Some transcriptional activators, e.g., GAL4 [26], NtrC [27,28] and SpoOA [29] bind DNA independent of their state of phosphorylation, but activate transcription efficiently only when phosphorylated. Purified, intact HepK, complete with its two presumptive transmembrane domains [10], had no detectable autokinase activity in vitro [7]. It is possible that the two presumptive transmembrane domains of intact HepK in vivo are responsible for sensing a signal specific to heterocyst development, and subsequently trigger autokinase activity of HepK in vivo. Although the soluble, truncated, recombinant form of HepK binds DNA independent of phosphorylation, the biological consequences of that binding may depend on whether HepK is phosphorylated. ToxR is a transmembrane transcriptional activator with a cytoplasmic DNA-binding domain [30]. Because truncated HepK binds site-specifically to DNA but has no known DNAbinding motif, it may be a prototype for a new class of proteinhistidine kinase that, like ToxR, serves also as a membranetethered transcription factor, which may also require an intramembrane proteolytic activation [31-33] in response to a signal specific to heterocyst development.

Genomic sequence data have identified no presumptive protein histidine kinase genes in animal genomes including human genome $[34,35]$. Since some two-component phos- 
phorelay proteins are essential for the viability, virulence, and drug resistance of microbial pathogens including human fungal and bacterial pathogens [36-39], novel anti-microbial drugs targeted to protein histidine kinase in two-component phosphorelay systems may prove high specificity and minimal toxicity $[\mathbf{4 0 , 4 1 ]}$. Several series of inhibitors to bacterial histidine kinase have been reported in the literature [42-44], however, most appear to suffer from high hydrophobicity, poor selectivity, and excessive protein binding and/or limited bioavailability [45]. The strong hydrophobicity of these molecules makes formulation and drug delivery impossible. Unlike these compounds, small DNA molecules bound specifically by a protein-histidine kinase HepK are able to bypass the drawbacks of conventional inhibitors. These sequence-specific small DNA molecules have several unique advantages in developing of novel anti-microbial drugs, such as high solubility, high specificity, minimal toxicity, efficient synthesis, easy of formulation and delivery. Therefore, our finding provides an exciting opportunity for developing small DNA molecules as novel anti-microbial drugs.

\section{Conclusion}

We have shown that although lacking a known DNA-binding motif, a truncated, soluble version of sensory protein-histidine kinase HepK binds sequence-specifically to a fragment of DNA found upstream from $h e p C$, a gene that is required for the synthesis of heterocyst envelope polysaccharide of cyanobacteria. The conserved phosphorylation histidine residue of HepK kinase is not required for this DNA-binding activity. Therefore, regulation of the synthesis of heterocyst envelope polysaccharide by HepK may be, at least in part, independent of two-component phosphorylation. For our best knowledge it is the first example of a protein histidine kinase without a known DNA binding motif that binds DNA sequence-specifically. Our finding may enable development of small DNA molecule as highly specific anti-microbial drugs because protein histidine kinases are broadly conserved in microbial pathogens but absent in humans.

\section{Competing interests}

The authors declare that they have no competing interests.

Authors' contributions

\begin{tabular}{|l|c|c|}
\hline Authors' contributions & RZ & OK \\
\hline Research concept and design & $\checkmark$ & $\checkmark$ \\
\hline Collection and/or assembly of data & $\checkmark$ & $\checkmark$ \\
\hline Data analysis and interpretation & $\checkmark$ & $\checkmark$ \\
\hline Writing the article & $\checkmark$ & $\checkmark$ \\
\hline Critical revision of the article & $\checkmark$ & $\checkmark$ \\
\hline Final approval of article & $\checkmark$ & $\checkmark$ \\
\hline Statistical analysis & -- & -- \\
\hline
\end{tabular}

Acknowledgement

We thank Dr. C. Peter Wolk (Michigan State University, E. Lansing,
MI) for work on the manuscript. We also thank Dr. Liping Gu for her insightful discussion and critical reading of the manuscript. This work was partially supported by NSF grant MCB0914691 (to R.Z.); and by the South Dakota Agricultural Experiment Station; and by the Biosciences Division, Office of Basic Energy Sciences, Office of Science, U.S. Department of Energy under grant DOE FG02-91ER20021.

Publication history

Editor: Zhang Cheng-Cai, Aix Marseille University, France. EIC: Tobias Alecio Mattei, Ohio State University, USA. Received: 18-Sep-2014 Final Revised: 21-Oct-2014 Accepted: 28-Nov-2014 Published: 04-Dec-2014

\section{References}

1. Grebe TW and Stock JB. The histidine protein kinase superfamily. Adv Microb Physiol. 1999; 41:139-227. I Article I PubMed

2. Loomis WF, Kuspa A and Shaulsky G. Two-component signal transduction systems in eukaryotic microorganisms. Curr Opin Microbiol. 1998; 1:643-8. | Article | PubMed

3. Stock AM, Robinson VL and Goudreau PN. Two-component signal transduction. Annu Rev Biochem. 2000; 69:183-215. | $\underline{\text { Article I PubMed }}$

4. Fabret $\mathrm{C}$, Feher VA and Hoch JA. Two-component signal transduction in Bacillus subtilis: how one organism sees its world. J Bacteriol. 1999; 181:1975-83. | Article | PubMed Abstract | PubMed Full Text

5. Shaulsky G, Fuller D and Loomis WF. A cAMP-phosphodiesterase controls PKA-dependent differentiation. Development. 1998; 125:691-9. | Article | PubMed

6. Stock JB and Koshland DE, Jr. A protein methylesterase involved in bacterial sensing. Proc Natl Acad Sci U S A. 1978; 75:3659-63. | Article | PubMed Abstract | PubMed Full Text

7. Zhou R and Wolk CP. A two-component system mediates developmental regulation of biosynthesis of a heterocyst polysaccharide. J Biol Chem. 2003; 278:19939-46. | Article | PubMed

8. Campbell EL, Hagen KD, Cohen MF, Summers ML and Meeks JC. The devR gene product is characteristic of receivers of two-component regulatory systems and is essential for heterocyst development in the filamentous cyanobacterium Nostoc sp. strain ATCC 29133. J Bacteriol. 1996; 178:2037-43. | Article | PubMed Abstract | PubMed Full Text

9. Liang J, Scappino $L$ and Haselkorn $R$. The pat $A$ gene product, which contains a region similar to CheY of Escherichia coli, controls heterocyst pattern formation in the cyanobacterium Anabaena 7120. Proc Natl Acad Sci U S A. 1992; 89:5655-9. | Article | PubMed Abstract | PubMed Full Text

10. Zhu J, Kong R and Wolk CP. Regulation of hepA of Anabaena sp. strain PCC 7120 by elements 5' from the gene and by hepK. J Bacteriol. 1998; 180:4233-42. | Article | PubMed Abstract | PubMed Full Text

11. Wolk C.P. Heterocyst formation in Anabaena. In Brun,Y.V. and Shimkets, L.J. (Eds.), Prokaryotic development. Am SocMicrobiol Press, Washington, DC. 2000; 83-104.

12. Tanaka T, Saha SK, Tomomori C, Ishima R, Liu D, Tong KI, Park H, Dutta R, Qin L, Swindells MB, Yamazaki T, Ono AM, Kainosho M, Inouye M and Ikura M. NMR structure of the histidine kinase domain of the E. coli osmosensor EnvZ. Nature. 1998; 396:88-92. | Article | PubMed

13. Wu J, Ohta N, Zhao JL and Newton A. A novel bacterial tyrosine kinase essential for cell division and differentiation. Proc Natl Acad Sci U S A. 1999; 96:13068-73. | Article | PubMed Abstract | PubMed Full Text

14. Yeh KC and Lagarias JC. Eukaryotic phytochromes: light-regulated serine/threonine protein kinases with histidine kinase ancestry. Proc Natl Acad Sci U S A. 1998; 95:13976-81. | Article | PubMed Abstract | PubMed Full Text

15. Ban C and Yang W. Crystal structure and ATPase activity of MutL: implications for DNA repair and mutagenesis. Cell. 1998; 95:541-52. I Article | PubMed 
Zhou et al. Trends in Bacteriology 2014,

16. Bilwes AM, Alex LA, Crane BR and Simon MI. Structure of CheA, a signaltransducing histidine kinase. Cell. 1999; 96:131-41. | Article I PubMed

17. Lau PC, Wang Y, Patel A, Labbe D, Bergeron H, Brousseau R, Konishi Y and Rawlings $\mathrm{M}$. A bacterial basic region leucine zipper histidine kinase regulating toluene degradation. Proc Natl Acad Sci U S A. 1997; 94:14538. | Article | PubMed Abstract | PubMed Full Text

18. Higuchi R. Recombinant PCR. In Innis,M.A., Gelfand,D.H., Sninsky,J.J. and White,T.J. (Eds.) PCR protocols: a guide to methods and applications. Academic Press, San Diego, CA. 1990; 177-183.

19. Wei TF, Ramasubramanian TS, Pu F and Golden JW. Anabaena sp. strain PCC 7120 bifA gene encoding a sequence-specific DNA-binding protein cloned by in vivo transcriptional interference selection. J Bacteriol. 1993; 175:4025-35. | Article | PubMed Abstract | PubMed Full Text

20. Koksharova OA and Wolk CP. Novel DNA-binding proteins in the cyanobacterium Anabaena sp. strain PCC 7120. J Bacteriol. 2002; 184:3931-40. | Article | PubMed Abstract | PubMed Full Text

21. Austin S, Buck M, Cannon W, Eydmann T and Dixon R. Purification and in vitro activities of the native nitrogen fixation control proteins NifA and NifL. J Bacteriol. 1994; 176:3460-5. | Article | PubMed Abstract | PubMed Full Text

22. Duclos B, Marcandier S and Cozzone AJ. Chemical properties and separation of phosphoamino acids by thin-layer chromatography and/or electrophoresis. Methods Enzymol. 1991; 201:10-21. | Article | PubMed

23. Blanco G, Drummond M, Woodley P and Kennedy C. Sequence and molecular analysis of the nifL gene of Azotobacter vinelandii. Mol Microbiol. 1993; 9:869-79. | Article | PubMed

24. Lee HS, Narberhaus F and Kustu S. In vitro activity of NifL, a signal transduction protein for biological nitrogen fixation. J Bacteriol. 1993; 175:7683-8. | Article | PubMed Abstract | PubMed Full Text

25. Woodley $P$ and Drummond $M$. Redundancy of the conserved His residue in Azotobacter vinelandii NifL, a histidine autokinase homologue which regulates transcription of nitrogen fixation genes. Mol Microbiol. 1994; 13:619-26. | Article | PubMed

26. Mylin LM, Johnston M and Hopper JE. Phosphorylated forms of GAL4 are correlated with ability to activate transcription. Mol Cell Biol. 1990; 10:4623-9. | Article | PubMed Abstract | PubMed Full Text

27. Porter S.C, North A.K and Kustu S. Mechanism of transcriptional activation by NtrC. In Hoch,J.A. and Silhavy,T.J. (Eds.), Two-component signal transduction. ASM Press, Washington, DC., 1995; 147-158.

28. Weiss V, Claverie-Martin F and Magasanik B. Phosphorylation of nitrogen regulator I of Escherichia coli induces strong cooperative binding to DNA essential for activation of transcription. Proc Natl Acad Sci U SA. 1992; 89:5088-92. | Article | PubMed Abstract | PubMed Full Text

29. Baldus JM, Green BD, Youngman P and Moran CP, Jr. Phosphorylation of Bacillus subtilis transcription factor Spo0A stimulates transcription from the spollG promoter by enhancing binding to weak $\mathrm{OA}$ boxes. J Bacteriol. 1994; 176:296-306. | Article | PubMed Abstract | PubMed Full Text

30. Miller VL, Taylor RK and Mekalanos JJ. Cholera toxin transcriptional activator toxR is a transmembrane DNA binding protein. Cell. 1987; 48:271-9. | Article | PubMed

31. Brown MS and Goldstein JL. The SREBP pathway: regulation of cholesterol metabolism by proteolysis of a membrane-bound transcription factor. Cell. 1997; 89:331-40. | Article | PubMed

32. Zhou R, Cusumano C, Sui D, Garavito RM and Kroos L. Intramembrane proteolytic cleavage of a membrane-tethered transcription factor by a metalloprotease depends on ATP. Proc Natl Acad Sci U S A. 2009; 106:16174-9. | Article | PubMed Abstract | PubMed Full Text

33. Chen K, Gu L, Xiang X, Lynch M and Zhou R. Identification and characterization of five intramembrane metalloproteases in Anabaena variabilis. J Bacteriol. 2012; 194:6105-15. | Article | PubMed Abstract | PubMed Full Text

34. Wolanin PM, Thomason PA and Stock JB. Histidine protein kinases: key signal transducers outside the animal kingdom. Genome Biol. 2002; 3:REVIEWS3013. | Article | PubMed Abstract | PubMed Full Text
35. Li D, Agrellos OA and Calderone R. Histidine kinases keep fungi safe and vigorous. Curr Opin Microbiol. 2010; 13:424-30. | Article I PubMed

36. Mascher T, Helmann JD and Unden G. Stimulus perception in bacterial signal-transducing histidine kinases. Microbiol Mol Biol Rev. 2006; 70:910-38. | Article | PubMed Abstract | PubMed Full Text

37. Catlett NL, Yoder OC and Turgeon BG. Whole-genome analysis of twocomponent signal transduction genes in fungal pathogens. Eukaryot Cell. 2003; 2:1151-61. | Article | PubMed Abstract | PubMed Full Text

38. Wang F, Tao J, Qian Z, You S, Dong H, Shen H, Chen X, Tang S and Ren S. A histidine kinase PmHHK1 regulates polar growth, sporulation and cell wall composition in the dimorphic fungus Penicillium marneffei. Mycol Res. 2009; 113:915-23. | Article | PubMed

39. Ryndak M, Wang S and Smith I. PhoP, a key player in Mycobacterium tuberculosis virulence. Trends Microbiol. 2008; 16:528-34. | Article | PubMed

40. Gotoh Y, Eguchi Y, Watanabe T, Okamoto S, Doi A and Utsumi R. Twocomponent signal transduction as potential drug targets in pathogenic bacteria. Curr Opin Microbiol. 2010; 13:232-9. | Article | PubMed

41. Stephenson K and Hoch JA. Two-component and phosphorelay signaltransduction systems as therapeutic targets. Curr Opin Pharmacol. 2002; 2:507-12. | Article | PubMed

42. Macielag MJ and Goldschmidt R. Inhibitors of bacterial two-component signalling systems. Expert Opin Investig Drugs. 2000; 9:2351-69. | Article I PubMed

43. Matsushita M and Janda KD. Histidine kinases as targets for new antimicrobial agents. Bioorg Med Chem. 2002; 10:855-67. | Article | PubMed

44. Stephenson K and Hoch JA. Developing inhibitors to selectively target two-component and phosphorelay signal transduction systems of pathogenic microorganisms. Curr Med Chem. 2004; 11:765-73. | Article I PubMed

45. Kaur K, Taneja NK, Dhingra S and Tyagi JS. DevR (DosR) mimetic peptides impair transcriptional regulation and survival of Mycobacterium tuberculosis under hypoxia by inhibiting the autokinase activity of DevS sensor kinase. BMC Microbiol. 2014; 14:195. | Article | PubMed Abstract I PubMed Full Text

\section{Citation:}

Zhou R and Koksharova OA. HepK, a protein-histidine kinase from the cyanobacterium Anabaena sp. strain PCC 7120, binds sequence-specifically to DNA. Trends Bacteriol. 2014; 1:3. http://dx.doi.org/10.7243/2057-4711-1-3 